\title{
Pengaruh variasi konsentrasi larutan belimbing wuluh (Averrhoa bilimbi) terhadap uji aktivitas antimikroba secara In vitro
}

\section{In vitro antimicrobial test for Averrhoa bilimbi extract at different level}

\author{
Desna Ayu Wijayanti, Osfar Sjofjan, Irfan H. Djunaidi * \\ Program Studi Magister Ilmu Ternak, Fakultas Peternakan Universitas Brawijaya \\ Jl. Veteran, Malang (65145)
}

Submitted: 15 Nopember 2018, Accepted: 26 Januari 2019

\begin{abstract}
ABSTRAK: Penelitian ini bertujuan untuk mengetahui nilai $\mathrm{pH}$ dan aktivitas antimikroba dari larutan buah belimbing wuluh (LBW) (Averrhoa bilimbi) sebagai pengganti antibiotik. Metode yang digunakan adalah metode percobaan dengan Rancangan Acak Lengkap dari 4 perlakuan dan 6 ulangan. Perlakuan terdiri dari $\mathrm{P} 0(+)=$ antibiotik (bacitracin), $\mathrm{P} 1=\mathrm{LBW} 10 \%, \mathrm{P} 2=\mathrm{LBW} 20 \%$ dan $\mathrm{P} 3=\mathrm{LBW}=40 \%$. Larutan belimbing wuluh yang digunakan berasal dari tepung buah belimbing wuluh yang kemudian dilarutkan. Variabel yang diukur dalam penelitian ini meliputi nilai $\mathrm{pH}$ serta diameter zona hambat dari Escherichia coli, Salmonella sp. dan BAL. Data dianalisis menggunakan ANOVA dan dilanjutkan dengan Uji Jarak Berganda Duncan. Hasil dari penelitian ini menunjukkan bahwa LBW dengan konsentrasi tertinggi menghasilkan nilai $\mathrm{pH}$ yang semakin rendah dan perlakuan antar perbedaan variasi konsentrasi memberikan pengaruh yang sangat nyata $(\mathrm{P}<0,01)$ terhadap diameter zona hambat dari Escherichia coli, Salmonella sp. dan BAL. Kesimpulan dari penelitian ini adalah LBW dengan konsentrasi $30 \%$ menghasilkan $\mathrm{pH}$ yang paling rendah sehingga menghambat pertumbuhan bakteri dan mempunyai potensi sebagai pengganti antibiotik karena menghasilkan aktivitas antimikroba yang paling baik.
\end{abstract}

Kata kunci : aktivitas antimikroba; Averrhoa bilimbi; diameter zona hambat; $\mathrm{pH}$

ABSTRACT: The purpose of this research to determine the $\mathrm{pH}$ value and the antimicrobial activity of bilimbi extract (LBW) as a substitute for antibiotics. The method was field experiment using Completely Randomize Design with 4 treatments and 6 replications. The treatments were consist of $\mathrm{PO}(+)$ $=$ antibiotic, $\mathrm{P} 1=\mathrm{LBW} 10 \%, \mathrm{P} 2=\mathrm{LBW} 20 \%$ and P3= LBW 30\%. Bilimbi extract used from bilimbi powder which is then dissolved. The measured variables were $\mathrm{pH}$ value and inhibition zone diameter of Escherichia coli, Salmonella sp. and Lactic Acid Bacteria. The data were analyzed by ANOVA and continued by Duncan's Multiple Range Test (DMRT). The result of this research showed that LBW with higher concentration produces low $\mathrm{pH}$ value and the treatments between variation of concentration gave significantly different effect $(\mathrm{P}<0.01)$ on diameter of inhibition zone for Escherichia coli, Salmonella sp. and Lactic Acid Bacteria. The conclusion of this research was 30\% concentration of LBW produces the lowest $\mathrm{pH}$ value, so that it can be inhibit the bacterial growth and has the potential as a substitute for antibiotics based on the result of antimicrobial activity that produces the best activity.

Keywords : antimicrobial activity; bilimbi; inhibition zone diameter; $\mathrm{pH}$

*Corresponding Author: irjuna@gmail.com

DOI: 10.21776/ub.jiip.2019.029.01.02 


\section{PENDAHULUAN}

Berbagai usaha telah dilakukan oleh peternak untuk meningkatkan keberhasilan dalam hal perbaikan populasi, kuantitas dan kualitas produk yang dihasilkan dengan cara meningkatkan efisensi pakan melalui penambahan antibiotik. Namun, beberapa tahun belakangan muncul kenyataan bahwa terdapat banyaknya strain mikroba patogen yang resisten terhadap antibiotik. Sebagai alternatif, perlu ditemukan bahan-bahan baru yang bersumber dari alam yang terbukti secara alamiah memiliki sifat antimikroba dan relatif lebih aman sebagai feed additive. Pemanfaatan buah dari berbagai tanaman sebagai sumber dari bahan alami untuk menemukkan senyawa aktif yang berpotensi sebagai sumber antimikroba baru terus diteliti. Salah satu buah yang dapat dimanfaatkan sebagai antimikroba adalah buah belimbing wuluh (Averrhoa bilimbi).

Buah belimbing wuluh, tergolong sumber asam organik yang mengandung beberapa jenis asam seperti asam asetat, asam sitrat dan asam format serta zat aktif lainnya seperti flavonoid, polifenol, tanin dan saponin (Datu, Mita dan Rusli, 2015) yang merupakan komponen farmakoseutika dan memiliki sifat penyangga, antibakteri dan antioksidan (Yuliansyah, Widodo dan Djunaidi, 2014). Zat aktif dan asam inilah maka pertumbuhan bakteri patogen akan dihambat. Kandungan asam yang mendasari perubahan $\mathrm{pH}$-lah yang diharapkan dapat menghambat atau membunuh Escherichia coli dan Salmonella sp. yang merupakan golongan bakteri gram negatif, sehingga dapat menggantikan atau setidaknya mampu menyamakan kemampuan dari antibiotik dalam menghambat pertumbuhan mikroba. Aktivitas dari asam organik akan menurunkan total mikroba, terutama efektif dalam melawan Escherichia coli dan jenis patogen lain seperti Salmonella sp. dan Campylobacter (Dibner and Buttin, 2002). Asam format dan asam propionat sangat efektif bekerja untuk per- lindungan terhadap pakan dan sebagai proteksi pakan terhadap kerusakan yang disebabkan oleh mikroba atau fungi (Mohammed, 2016).

Uji aktivitas antimikroba atau uji daya hambat merupakan salah satu uji in vitro yang dapat digunakan untuk mengetahui suatu bahan alami tersebut memiliki potensi sebagai sumber antimikroba yang baik dan memiliki kemampuan untuk menghambat pertumbuhan mikroba. Uraian diatas menjadi hal yang menarik untuk dilakukan pengukuran nilai $\mathrm{pH}$ dan uji daya hambat dari buah belimbing wuluh terhadap pertumbuhan bakteri Escherichia coli, Salmonella sp., dan Lactobacilli.

\section{MATERI DAN METODE \\ Waktu dan lokasi penelitian}

Penelitian berlangsung pada 22-23 Oktober 2018. Penelitian dilakukan untuk mengetahui pengaruh perubahan $\mathrm{pH}$ dari larutan belimbing wuluh terhadap aktivitas penghambatan mikroba dan mengetahui aktivitas antimikroba dengan uji daya hambat mikroba menggunakan isolat bakteri uji dari hasil biakkan sebanyak $10^{6}$ $\mathrm{cfu} / \mathrm{ml}$ (Escherichia coli, Salmonella sp., dan Lactobacilli). Pengukuran $\mathrm{pH}$ dari larutan belimbing wuluh dilakukan di Laboratorium Teknologi Hasil Ternak, Fakultas Peternakan Universitas Brawijaya dan untuk uji daya hambat dilakukan di Laboratorium Hama dan Penyakit Tanaman, Fakultas Pertanian Universitas Brawijaya.

\section{Material penelitian}

Penelitian ini menggunakan larutan belimbing wuluh yang berasal dari tepung buah belimbing wuluh. Pemanenan buah belimbing wuluh didapat dari beberapa kawasan di area Malang raya yang merupakan dataran tinggi dengan ketinggian sekitar 440-667 m diatas permukaan laut dengan keadaan suhu kisaran $18-23^{\circ} \mathrm{C}$ dan kelembaban rata rata tahunan $77,15 \%$. Sampel tepung belimbing wuluh yang 
dibutuhkan untuk dijadikan sebagai larutan sebanyak $100 \mathrm{~g}$ yang berasal dari $5 \mathrm{~kg}$ buah belimbing wuluh segar. Bahan lain yang dibutuhkan seperti aquades, antibiotik (bacitracin), kertas cakram $5 \mathrm{~mm}$, jangka sorong, biakan murni bakteri (Escherichia coli, Salmonella sp., dan Lactobacilli) yang diinokulasikan secara aseptik kedalam media NA (Nutrient Agar) dan sudah diinkubasi selama 24 jam di suhu $37^{\circ} \mathrm{C}$, dan media NA (Nutrient Agar). Peralatan yang diperlukan yaitu $\mathrm{pH}$ meter, cawan petri, kawat ose, jangka sorong, kertas cakram dan inkubator.

\section{Metode}

Metode yang digunakan dalam penelitian merupakan metode percobaan, terdiri dari 4 perlakuan dan 6 ulangan. Adapun perlakuan tersebut sebagai berikut:

\begin{tabular}{|c|c|c|}
\hline $\mathrm{P} 0(+)$ & & $\begin{array}{l}\text { Isolat bakteri }+ \text { antibiotic } \\
\text { (bacitracin) }\end{array}$ \\
\hline $\mathrm{P} 1$ & & $\begin{array}{l}\text { Isolat bakteri + larutan konsentra- } \\
\text { si belimbing wuluh (LBW) } 10 \%\end{array}$ \\
\hline $\mathrm{P} 2$ & & $\begin{array}{l}\text { Isolat bakteri + larutan konsentra- } \\
\text { si belimbing wuluh (LBW) } 20 \%\end{array}$ \\
\hline P3 & & $\begin{array}{l}\text { Isolat bakteri + larutan konsentra- } \\
\text { si belimbing wuluh (LBW) } 30 \%\end{array}$ \\
\hline
\end{tabular}

Variabel yang diamati adalah diameter zona hambatan dari bakteri Escherichia coli, Salmonella sp., dan Lactobacilli. Respon adanya potensi dari suatu larutan memiliki sifat antibakteri ditentukan dengan mengukur zona hambatan bakteri pada permukaan atas agar yang terlihat bening menggunakan metode paper disc dengan mengukur luas diameter hambatan dikurangi dengan diameter dari kertas (Soleha, 2015).

\section{Analisis data}

Analisa data yang digunakan dalam penelitian adalah ANOVA dari rancangan acak lengkap dan akan dilanjutkan dengan uji jarak berganda Duncan apabila hasil menunjukkan adanya perbedaan. Tujuan dari analisis ini untuk menjelaskan dan mengetahui perlakuan dari variasi konsentrasi larutan belimbing wuluh mana yang terbaik untuk bisa menghasilkan aktivitas antimikroba sehingga dapat menggantikan perlakuan kontrol atau antibiotik.

\section{HASIL DAN PEMBAHASAN Nilai pH}

Hasil pengukuran $\mathrm{pH}$ dari masingmasing larutan konsentrasi belimbing wuluh ditunjukkan pada Tabel 1.

Tabel 1. Perubahan $\mathrm{pH}$ dari larutan konsentrasi belimbing wuluh (LBW).

\begin{tabular}{cc}
\hline Larutan konsentrasi (\%) & $\mathrm{pH}$ \\
\hline Belimbing wuluh 10 & 1,8 \\
Belimbing wuluh 20 & 1,5 \\
Belimbing wuluh 30 & 1,3 \\
\hline
\end{tabular}

Data diatas menunjukkan data hasil dari pengukuran $\mathrm{pH}$ LBW dari masing masing larutan konsentrasi yang berbeda. Hasil pada Tabel 1 , terlihat bahwa nilai $\mathrm{pH}$ yang dihasilkan bervariasi dari masing-masing perlakuan. Keasaman dari larutan belimbing wuluh ini tidak terlepas dari kandungan asam organik yang memang terdapat pada buah belimbing wuluh (Rahmi, 2015). Penurunan $\mathrm{pH}$ ditunjukkan dengan semakin besarnya larutan dengan konsentrasi belimbing wuluh yang besar. Meskipun $\mathrm{pH}$ terendah diperoleh pada perlakuan LBW $30 \%$, namun terlihat $\mathrm{pH}$ antar variasi LBW tidak terlalu berbeda diantara semua perlakua masih termasuk dalam kategori sangat asam.

Perubahan $\mathrm{pH}$ diantara perlakuan yang semakin asam diharapkan dapat memberikan pengaruh terhadap kemampuannya menghambat pertumbuhan mikroba yang semakin kuat. Sebab, penurunan nilai $\mathrm{pH}$ 
dapat memberikan efek antibakteri dan antijamur dalam pakan yang merupakan salah satu prinsip kerja dari sumber asam organik atau acidifier (Luckstadt and Mellor, 2011). Selain dari tingginya konsentrasi, besarnya daya antibakteri dari suatu jenis asam juga bergantung pada besar nilainya $\mathrm{pH}$ (Chaveerach et al, 2002). Dibner and Buttin (2002) menjelaskan bahwa hampir semua jenis asam memiliki aktivitas antibakteri yang kuat dalam menghambat mikroba, termasuk jenis asam yang terkandung didalam belimbing wuluh seperti asam sitrat, asam asetat, asam format, asam laktat dan asam oksalat.

\section{Uji aktivitas antimikroba}

Hasil penelitian menunjukkan bahwa penggunaan LBW menunjukkan pengaruh yang sangat nyata $(\mathrm{P}<0,01)$ terhadap kemampuan daya hambat Escherchia coli, Salmonella sp. dan BAL. Tabel 2 menunjukkan hasil daya hambat mikroba dari LBW yang hasilnya dibandingkan dengan antibiotik.

Tabel 2. Daya hambat mikroba antibiotik dan larutan belimbing wuluh (mm).

\begin{tabular}{cccc}
\hline Perlakuan & Escherchia coli & Salmonella sp. & BAL \\
\hline P0 (+) & $10,55 \pm 0,23^{\mathrm{d}}$ & $8,07 \pm 0,42^{\mathrm{d}}$ & $9,3 \pm 0,78^{\mathrm{b}}$ \\
P1 & $4,8 \pm 0,28^{\mathrm{a}}$ & $2,88 \pm 0,20^{\mathrm{a}}$ & $4,8 \pm 0,46^{\mathrm{a}}$ \\
P2 & $5,85 \pm 0,34^{\mathrm{b}}$ & $3,68 \pm 0,44^{\mathrm{b}}$ & $5,0 \pm 0,51^{\mathrm{a}}$ \\
P3 & $6,8 \pm 0,85^{\mathrm{c}}$ & $5,07 \pm 0,41^{\mathrm{c}}$ & $5,2 \pm 0,46^{\mathrm{a}}$ \\
\hline
\end{tabular}

Keterangan: notasi yang berbeda pada kolom yang sama menunjukkan perbedaan yang sangat nyata $(\mathrm{P}<0,01)$.

Tabel 2, penghambatan terbesar yaitu pada Escherchia coli baik pada antibiotik maupun antar LBW. Selain adanya kandungan asam, senyawa antimikroba yang terdapat pada LBW ternyata juga mampu menghambat pertumbuhan dari golongan bakteri gram negatif yaitu Escherchia coli dan Salmonella sp. Respon adanya potensi dari sifat antimikroba suatu larutan terlihat dari seberapa besar zona bening yang terbentuk di atas permukaan agar. Besarnya diameter zona hambat menunjukkan bahwa zat antimikroba yang terdapat dalam larutan tersebut memiliki kemampuan dalam menghambat pertumbuhan mikroba juga besar, semakin tinggi konsentrasi dari suatu zat antimikroba maka semakin besar pula diameter (clear zone) yang terbentuk (Rahmawati, Sudjarwo dan Widodo, 2014).

Hasil penelitian yang disajikan pada Tabel 2, dapat diketahui bahwa aktivitas penghambatan mikroba baik pada Escherchia coli dan Salmonella sp. yang diperoleh dari pengukuran diameter paling tinggi ditunjukkan pada perlakuan P3 yang memiliki konsentrasi LBW paling tinggi. Semakin tinggi konsentrasi LBW maka semakin besar pula penghambatan terhadap mikroba. Perlakuan P1 dan P2, sama-sama memiliki kemampuan penghambatan terhadap mikroba yang baik sebesar 4,8 \pm $0,28 \mathrm{~mm}$ dan $5,85 \pm 0,34 \mathrm{~mm}$ menunjukkan bahwa sebenarnya dengan konsentrasi tersebut asam organik yang terkandung dalam larutan tersebut sudah mampu untuk menciptakan aktivitas antimikroba. Perbedaan hasil P1, P2 dan P3 ini diduga terkait dengan adanya kandungan asam organik dan nilai $\mathrm{pH}$ pada masing-masing larutan yang semakin tinggi konsentrasinya maka $\mathrm{pH}$ semakin turun dan kandungan asam organik semakin besar.

Penghambatan terbesar terhadap mikroba dan nilainya hampir mendekati besar hambatan dari antibiotik (P0) ditunjukkan pada perlakuan P3 yaitu pada LBW 30\% yang juga pada larutan tersebut memiliki $\mathrm{pH}$ yang rendah yaitu 1,3. Nilai tersebut menunjukkan nilai $\mathrm{pH}$ yang sangat asam dan diduga dengan rendahnya $\mathrm{pH}$ tersebut 
maka akan menghambat dan membunuh mikroba. Frazier and Westhoff (1998) menyatakan bahwa efektifitas antimikroba dipengaruhi oleh beberapa faktor, satu diantaranya merupakan tingkat keasaman $(\mathrm{pH})$. Hal ini membuktikan bahwa peran yang bersumber dari asam organik mampu berperan besar sebagai antibakteri.

LBW dari semua konsentrasi mampu menghambat pertumbuhan dari bakteri gram negatif yaitu Escherchia coli lebih besar dibandingkan dengan bakteri uji lainnya. Perbedaan daya hambat ini disebabkan oleh perbedaan dari dinding sel bakteri (Kurniawan, 2018). Hal tersebut disebabkan dari mekanisme kerja dari asam organik dalam menghambat aktivitas bakteri. Yuk and Marshall (2005) menjelaskan bahwa asam berdisosiasi dan menghasilkan ion hidrogen, dari situlah apabila jumlah asam yang tidak terdisosiasi banyak yang masuk ke dalam sel sehingga jumlah ion hidrogen yang dihasilkan semakin banyak dan terjadi pengasaman sel (penurunan $\mathrm{pH}$ sitoplasma), akibatnya akan merusak membran dari sitoplasma dan bakteri akan rusak atau mati.

Terkait dengan pengujian sebelumnya, nilai $\mathrm{pH}$ yang terbentuk (lihat Tabel 1) berkisar antara 1,3-1,8. Nilai $\mathrm{pH}$ yang rendah tersebut sangat memungkinkan dalam memaksimalkan penghambatan bakteri terutama pada golongan bakteri gram negatif, karena umumnya mikroba dapat tumbuh pada kisaran $\mathrm{pH}$ 6-8. Sutrisna, Ekowati dan Sinaga (2015) menyatakan bahwa Salmonella sp. hanya dapat berkembang biak dan bertahan hidup pada pH 6,5-7,5 meskipun masih dapat mempertahankan hidup pada $\mathrm{pH} 4$.

Selain dari pengaruh $\mathrm{pH}$ yang memberikan efek dari aktivitas antimikroba, kandungan jenis asam organik yang terkandung dalam buah belimbing wuluh juga berpengaruh. Asam asetat dan asam laktat merupakan dua diantara jenis asam organik yang terkandung dalam buah belimbing wuluh. Andriani, Darmono dan Kurniawati
(2007) menjelaskan bahwa asam asetat memiliki aktivitas antimikroba yang lebih besar dibandingkan asam laktat karena nilai pKa yang dimiliki asam asetat jauh lebih tinggi dibandingkan degan asam laktat, namun keduanya sama-sama memiliki sifat sebagai antibakteri dalam menghambat Salmonella sp. Kandungan asam organik lainnya seperti asam sitrat, asam sormat dan asam oksalat juga saling bersinergi sehingga mempercepat kerusakan dan proses kematian dari sel mikroba.

\section{KESIMPULAN DAN SARAN}

Larutan buah belimbing wuluh konsentrasi $30 \%$ menghasilkan nilai $\mathrm{pH}$ yang paling rendah yang mampu menghambat pertumbuhan bakteri sehingga menghasilkan aktivitas antimikroba yang paling baik. Penggunan dari larutan buah belimbing wuluh atau tepung buah belimbing wuluh sebagai feed additive dapat dijadikan sebagai alternatif pengganti dari penggunaan antibiotik pada pakan ternak unggas.

\section{DAFTAR PUSTAKA}

Andriani., Darmono., dan Kurniawati, W. 2007. Pengaruh asam asetat dan asam laktat sebagai antibakteri terhadap bakteri Salmonella sp. yang diisolasi dari karkas ayam. Seminar Nasional Teknologi Peternakan dan Veteriner, (pp. 930-934). Bogor.

Chaveerach, P., Keuzenkamp, D.A., Urlings, H.A., Lipman, L.J., and Knapen, F. 2002. In vitro study on the effect of organic acids on Campylobacter jejuni/coli populations in mixtures of water and feed. Poultry Science, 81(5), 621-628. doi: https://doi.org/10.1093/ps/81.5.621

Datu, J. T., Mita, N., dan Rusli, R. 2015. Aktivitas antibakteri sari buah belimbing wuluh (Averrhoa bilimbi linn.) terhadap bakteri Pseudomonas aeruginosa dan Staphylococcus epi- 
dermis. Prosiding Seminar Nasional Kefarmasian Ke-1, (pp. 1-9). Universitas Mulawarman, Kalimantan Timur.

Dibner, J.J., and Buttin, J. 2002. Use of organic acids as a model to study the impact of gut microflora on nutrition and metabolism. The Journal of Applied Poultry Research. 11(4), 453463.doi:https://doi.org/10.1093/japr/1 $\underline{1.4 .453}$

Frazier, W.C., and Westhoff, D.C. 1998. Food Microbiology (4th ed.). Mc Graw-Hill Book Co, New York.

Kurniawan, D. 2018. Aktivitas antimikroba dan antioksidan ekstrak tepung daun dan buah mengkudu (Morinda citrifolia). Jurnal Ilmu-Ilmu Peternakan, 28(2), 105-111.

doi:10.21776/ub.jiip.2018.028.02.02.

Luckstadt, C., and Mellor, S. 2011. The use of organic acids in animal nutrition, with special focus on dietary pottasium diformate under European and Austral-Asian conditions. Recent Advances in Animal Nutrition. 18(11), 123-130.

Mohammed, H. A. 2016. Effect of utilization organic acid supplement on broiler (ros-308) feeding at prestarter and starter period breeding on basic performance parameters. International Journal of Advanced Research in Biological Sciences, 3(6), 76-81. doi: s-o-i.org/1.15/ijarbs2016-3-6-10

Rahmawati, N., Sudjarwo, E., dan Widodo, E. 2014. Uji aktivitas antibakteri ekstrak herbal terhadap bakteri Escherichia coli. Jurnal Ilmu-Ilmu Peternakan, 24(3), 24-31.
Rahmi, F. 2015. Pembuatan bubuk asam sunti melalui optimasi suhu dan lama pengeringan. Jurnal Teknologi dan Industri Pertanian Indonesia, 7(2), 53-56.

doi:dx.doi.org/10.17969/jtipi.v7i2.32 $\underline{78 .}$

Soleha, T. A. 2015. Uji kepekaan terhadap antibiotik. Jurnal Kedokteran, 5(9), 119-123.

Sutrisna, R., Ekowati, C.N., dan Sinaga, E. 2015. Pengaruh $\mathrm{pH}$ terhadap produksi antibakteri oleh bakteri asam laktat dari usus itik. Jurnal Penelitian Pertanian Terpadu, 15(3), 234-238.

doi: 10.25181/jppt.v15i3.135.

Yuk, H.G., and Marshall, D.L. 2005. Influence of acetic, citric, and lactic acids on Escherichia coli 0157:H7 membrane lipid composition, verotoxin secretion, and acid resisteance in simulated gastric fluid. Journal of Food Protection, 68(4), 673-679. doi: 10.4315/0362-028X-68.4.673.

Yuliansyah, M. F., Widodo, E., dan Djunaidi, I. H. 2014. Pengaruh penambahan sari buah belimbing wuluh (averrhoa bilimbi l) sebagai acidifier dalam pakan terhadap kualitas internal telur ayam petelur. Jurnal Nutrisi Ternak. 1(1), 19-26. 